\title{
Production, Characterization and Application of a New Biosurfactant Derived from Egyptian Sunflower Seeds
}

\author{
A. Diab ${ }^{1}$, Shereen Sami $^{2}$, A. A. Diab ${ }^{3}$ \\ Faculty of Biotechnology, October University for Modern Sciences and Arts (MSA), Egypt
}

\begin{abstract}
A new biosurfactant (SR122) was obtained for the first time from the seeds of sunflower plant growing locally in Egypt. This bioproduct was recovered from the seeds using simple and cost effective method that gave higher biosurfactant yield (20-25\% w/w). The new product (SR 122) may be an alternative to the microbial and synthetic surfactants because it is non toxic (as it was originated from safe natural sources- the plant), cost-effective, produced in higher yield (as compared to the microbial biosurfactant) and may acquire public acceptance. The high surface activity of SR 122 (as measured by the ODA method, surface tension reduction and E24 method), the non-toxicity and tolerance to wide range of harsh condition of temperatures (up to $121^{\circ} \mathrm{c}$ ), $\mathrm{pH}$ values (2-11) and different NaCl concentrations $(2 \%-25 \% \mathrm{w} / \mathrm{v})$ make this new product a promising candidate for the application in many industries and for the protection of the environment. On a large laboratory scale SR122 was applied for cleaning oil storage tank. During the cleaning process more than $95 \%$ of the oily sludge was recovered and the viscosity of the recovered oil was decreased allowing the oily sludge to be easily floated on the top of the biosurfactant as a distinct phase. This product SR 122 was offered for a patent no: 1289/2014
\end{abstract}

Keywords: New biosurfactant, Sunflower seed meal, Application, Cleaning oil storage vassels, Bioremediation, Patent.

\section{Introduction}

Surfactant are one of two main groups, chemically synthesized surfactants and biosurfactants (which are directly derived from natural sources such as plants, microorganisms and animals).

Biosurfactants have the advantages over the chemically synthesized surfactants due to their biodegradbility, low or no toxicity, low irritability, compatibility with human skin and ecologically acceptable. They are termed "environmental friendly" and "green products" (Banat et al, 2000).

Many environmental and agriculture activities are important areas for biosurfactant applications. They play important roles in soil remediation, oil recovery and plant pathogen elimination. They are also used in detergents, paints, coatings, cosmetics pharmaceutical and food industries (Mukherjee et al, 2006).

In recent years, researches in the area of biosurfactants has expanded due to their use in different industrial activities. The development of such research represent the important role of these biological compounds for the protection of the environment (Khopode et al, 2012).

A variety of biosurfactants are derived from plants (termed phytogenic biosurfactants) such as saponins, lecithin, soyprotein and soybean oil. Saponins are widely distributed among plants. The most significant source of dietry saponins are legume plants such as soybeans, broad beans, peanuts, kidney beans and lenticells (Xu et al, 2011; Oakenfull, 1981).

Saponins have emulsifying and foam properties and are used in medicine, beverages, conflectionary, cosmetics and pharmaceuticals. They also have antimicrobial and insecticidal activities (Venken et al, 2007).

Licithin is a low molecular weight natural surfactant found in both plants and animals. It is derieved from soybean seeds due to its abundance and low cost. Soylecithin is used or emulsifier, antioxidant, stabilizer, lubricant, wetting agent and nurritional supplement (Li, 2006).

Although the microbial biosurfactants have many advantages, they are of limited global industrial production due to the expensive raw materials, low production yield and high purification cost necessary for food, cosmetic and pharmaceutical applications. Also the industrial application of biosurfacants is limited by a lack of public acceptance of the biosurfactant- producing microorganisms (Zhang et al, 2012; Xu et al, 2011).

For the above reasons surfactant of plant origin are alternative for both the chemically synthesized surfactants and the microbial biosufactants in many applications. They gain public acceptance as they derived from safe natural source- the plants. At the same time they are cost effective and may be derived in high quantities.

To the best of our knowledge, no studies are available describing any surface active compounds derived from sunflower plants especially their seeds. Accordingly we are the first investigators studying the extraction, characterization and certain applications of this type of phytogenic biosurfatance (here known as SR 122).

\section{Materials and Methods}

(1) Extraction of the biosurfactant SR 122.

The biological product SR 122 was extracted from the seed meal of sunflower plant by the solvent ethylacetate. The solvent was evaporated leaving behind a yellowish oily 


\section{International Journal of Science and Research (IJSR) \\ ISSN (Online): 2319-7064}

Index Copernicus Value (2013): 6.14 | Impact Factor (2014): 5.611

product. This product was diluted with distilled water or tap water ( $\mathrm{pH} 8.5-9)$ to a level of 1/25-1/400 (i.e. 4 to $0.25 \% \mathrm{w} / \mathrm{v}$, forming stable milky solution.

\section{(2) Measurement of the surface activity of SR 122}

\section{2-1 Oil displacement test}

This method was carried out according to Techaoei et al (2011). The method is sensitive, in which only small amount of sample is required to measure the activity of the product. The size of the developed oil displacement circle area reflects the activity of the biosurfactant. The larger the size, the higher the activity (Hamza et al, 2013). This method is carried out as follows:

- Fifty $\mathrm{ml}$ sea water or distilled water was introduced into large perti dish (15 cm diam) $40 \mathrm{ul}$ of light crude oil or motor oil was spread on the surface of the water.

- 20 ul of each dilution of the bioproduct SR 122 was placed on the oil film in the petridish.

- The diameter of clear zone circle was measured, and then the area of the clear circle was calculated and expressed as ODA $\mathrm{cm}^{2}$ (oil displacement area)

\section{2-2 The 12 wells porcelain method}

This method was developed by Diab and Diab (2014), "work not published" as follows:

- 12 wells porcelain plates were used. Each clean well was coated by a film of oil.

- $10 \mathrm{ul}$ of each dilution of SR 122 was added to each oilcoated well.

- After one minute the developed clear zones and/or the collapse of the oil were observed.

This method is sensitive and requires small amount of the product. The developed expel oil clear zone and/or the collapse of the oil are clearly observed and recorded (Fig. 1).

\section{2-3 Emulsification index (E24).}

This method was carried out according to Tabatabee et al (2005) and Techaoei et al (2011) as follows:

a) In a screw caped tube, $4 \mathrm{ml}$ of dilution 1/150 (w/v) of the bioproduct SR 122 was added to $4 \mathrm{ml}$ of each of the following:

- Crude oil mixed with kerosene $(1: 1)$

- Crude oil

- Kerosene

- Used motor oil

- Paraffin oil

- Corn oil

- Soybean oil

- Sunflower oil

- Olive oil

b) The tubes were vortexed at high speed for two minutes. The mixture was left to settle for $24 \mathrm{~h}$, after which the E24 was calculated as follows:

$E_{24}=\frac{\text { The height of the emulsion layer }}{\text { The total height of the mixture }} \times 100$

The ability of a biosurfactants to form stable emulsion with vegetable oils suggests potential application in food and pharmaceutical industries, while the ability to form stable emulsion with petroleum hydrocarbons suggests valuable applications in petroleum industries. An emulsion is considered stable if its volume after $24 \mathrm{~h}$ corresponds to $50 \%$ or more (Lima et al, 2011). Higher E24 more than 50\% suggests potential application of the bioproduct (Gnanamani et al., 2010).

\section{2-4 Measurement of the surface tension:}

The surface tension of the extracted bioproduct and its dilutions $1 / 100,1 / 150$ and $1 / 300(1 \%, 0.7 \%$ and $0.3 \% \mathrm{w} / \mathrm{v})$ were measured by a tensiometer. For the caliberation of the tensiometer, the surface tension of pure water that was used for making the different dilutions of the product was measured.

\section{(3) Stability of the Biosurfactant SR 122}

\section{3-1 Thermostability Test}

This method was carried and according to Techaoei et al (2011) and Haddad et al (2009) as follows:

Ten $\mathrm{ml}$ portions of SR122 solution $(0.7 \% \mathrm{w} / \mathrm{v})$ were exposed to various temperatures $\left(50-121 \mathrm{c}^{\circ}\right)$ for $20 \mathrm{~min}$. allowed to cool at room temperature and the activity of the product was measured by using the ODA method.

\section{3-2 Effect of different pH values}

The biosurfactant SR 122 solution $(0.7 \% \mathrm{w} / \mathrm{v})$ was adjusted to different $\mathrm{pH}$ values (2-11). The activity of the biosurfactant SR 122 was measured at each $\mathrm{pH}$ value by using the ODA method.

\section{3-3 Effect of salinity:}

The effect of $\mathrm{NaCl}$ concentrations was carried out by adding different concentration of $\mathrm{NaCl}(0 \%-25 \%$ w/v) to the SR 122 solution and allowed to stand for $30 \mathrm{~min}$ after which the activity in each concentration was measured by the ODA method.

(4) Application of the biosurfactant SR 122 for cleaning Oil-contaminated Vessels

Different dilutions of the biosufactant SR 122 (1/100, 1/150, $1 / 200$ and 1/300) were used for cleaning oil-contaminated vessels using the method described by Diab and El-Din (2013) as follows:

- Five tubes were fillad with crude petroleum oil and left stagnant for $96 \mathrm{~h}$

- The tubes were emptied leaving their walls and bottoms contaminated with the oil.

- A known volume $(10 \mathrm{ml})$ of each dilution of SR 122 was gently introduced into each tube. The remaining one tube received water only as control

- The results were observed and recorded within 2-30 min.

On a large laboratory scale SR 122 at dilution 1/100 was applied for cleaning a microcosm representing oil-storage tank. The microcosm was represented by a tank $(50 \times 30 \times 30 \mathrm{~cm})$. In this tank crude oil was stored for a period of 24 month.

- At the end of the storage period, the tank was emptied, leaving its bottom covered with the oily sludge.

- Three liters of the biosurfactant $(1 / 100 \mathrm{w} / \mathrm{v})$ were introduced into the tank. The tank was located on a shaker operated at $120 \mathrm{rpm}$, for a period of $96 \mathrm{~h}$.

- The results were observed and recorded periodically. 


\section{International Journal of Science and Research (IJSR) \\ ISSN (Online): 2319-7064}

Index Copernicus Value (2013): 6.14 | Impact Factor (2014): 5.611

\section{Results and Discussion}

The new bioproduct SR 122 was extracted from the seeds of the Egyptian sunflower plant in the form of a yellowish oily material. This oily product was able to reduce the surface tension to $42 \mathrm{~m} \mathrm{Nm}^{-1}$, had oil displacement area of $39.4 \mathrm{~cm}^{2}$ and gave milky solution when it was diluted with water ( $\mathrm{pH} 8.5$-9).(this SR 122 biporduct was offered for a patent No 1289/2014). Different dilutions of $1 / 10$ to 1.400 $(\mathrm{w} / \mathrm{v})$ of this bioproduct were prepared and tested for their surface activities by using the 12 well porcelain plate (Fig 1) and the oil displacement area (ODA) methods. All of the dilutions tested showed positive interfacial tension reduction for the two methods (Table 1, Figs 1-3). It must be noted that the 12 well porcelain plate method is based on the reduction of the interfacial tension between petroleum oil and solid surfaces. While the ODA method is based on the reduction of the interfacial tension between oil and water. The higher ODA $\mathrm{cm}^{2}$ values were recorded with dilutions $1 / 50,1 / 100$ and $1 / 150(153.8 \pm 3.2,171.9 \pm$ 0.0 and $165.1 \pm 3.1$ respectively). A notable distinction character of SR 122 is that increased ODA values were observed with the increase of dilution rates from $1 / 10$ $\left(95.0 \mathrm{~cm}^{2}\right)$ to $1 / 200\left(103.8 \pm 305 \mathrm{~cm}^{2}\right)$ with optimum values at $1 / 100\left(171.9 \pm 0.0 \mathrm{~cm}^{2}\right)$ and $1 / 150(165.1 \pm 3.1$ $\mathrm{cm}^{2}$ ).

This character may be used to distinguish biosurfactant of plant origin from those of microbial origin. Periera et al (2013) demonstrated that surface tension increased with decreasing the concentration of the biousrfactants produced by three strains of Bacillus subtilis. They found that the non-diluted biosurfactants reduced surface tension to $28.1-29.4 \mathrm{mNm}^{-1}$, and $1 / 10$ dilution reduced surface tension to 32.8 - $35.0 \mathrm{mNm}^{-1}$ while dilutions of $1 / 100$ reduced the surface tension to $46.2-70 \mathrm{mNm}^{-1}$.

Results of the surface tension reduction show that the higher surface tension reduction was achieved by dilution $1 / 100(29 \mathrm{mNm})$ followed by dilution $1 / 150(37.0 \mathrm{mNm})$ and dilution $1 / 200(51 \mathrm{mNm})$.

As we mentioned before, the highest ODA values were recorded when dilutions $1 / 50,1 / 100$ and $1 / 150$ of SR 122 were examined $(153.8 \pm 3.2,171.9 \pm 0.0$ and $165.1 \pm 3.1$ $\mathrm{cm}^{2}$ respectively). Referring to Table (2) our ODA values represent the highest values when compared to those recorded by other biosurfactants. In this table the highest ODA values recorded were $143.2 \mathrm{~cm}^{2}$ and $110.6 \mathrm{~cm}^{2}$ by Pseudomonas aeruginosa SCMU/O6 (Techoaei et al, 2011). A part from these values, the table also show that no ODA values higher than $69.43 \mathrm{~cm}^{2}$ were recorded (Thaniyvarm et al, 2008). Accordingly, it is the first time to find a biological surfactant, especially of plant origin that is able to produce these highest ODA values especially when diluted to $1 / 50-1 / 150$.

Hamza et al (2013) screened 20 bacteria for biosurfactant production by using the oil spread method, microplate method and drop collapse method. They found that $45 \%$ of the bacterial isolates were positive for the oil spread method (oil displacement area ODA). They recorded the results as follows:

+ : Clear zone diameter of 5-9 $\mathrm{mm}\left(0.2-0.6 \mathrm{~cm}^{2}\right.$ ODA $)$
++ : Clear zone diameter of $10-15 \mathrm{~mm}\left(0.8-1.8 \mathrm{~cm}^{2}\right.$ ODA $)$

+++ : Clear zone diameter of $>15-<21 \mathrm{~mm}\left(>1.8-<3.4 \mathrm{~cm}^{2}\right.$ ODA)

++++ : Clear zone diameter of $>21-<30 \mathrm{~mm}\left(>3.46-<7.1 \mathrm{~cm}^{2}\right.$ ODA)

Tambekar et al (2013) screened 14 bacteria for biosurfacant production using the oil spread method, the drop collapse method and B-haemolysis test. They considered $5 \mathrm{~mm}$ and 10 $\mathrm{mm}$ diameter clear zones as positive biosurfactant production by the oil spread method. They recorded 13 bacterial strain $(92.9 \%)$ as positive biosurfactant producers by using the oil spread method. Techaoei et al (2011) isolated 25 bacterial isolates from garage sites, all of the 25 bacterial strains were biosurfactant producer when they were tested by the oil displacement area (ODA) method. They recorded this results as follows:

+: Oil displacement area (ODA) of $0.1-3.14 \mathrm{~cm}^{2}$

++ : Oil displacement area (ODA) of 3.4-12.57 $\mathrm{cm}^{2}$

+++ : Oil displacement area (ODA) of $12.57-28.28 \mathrm{~cm}^{2}$

++++ : Oil displacement area (ODA) of $>28.28 \mathrm{~cm}^{2}$

The excellent interfacial reduction character of the bioproduct SR 122 as indicated by the oil displacement area and the 12 wells porcelain plate methods give this product a potential application for enhanced oil recovery from reservoirs due to the reduction of the interfacial tension between oil and water and the reduction of the capillary force between oil and the reservoir rocks which lead to increase mobilization of the oil in the reservoir (Periera et al, 2013).

The results of the emulsification activity of SR 122 as measured by the emulsification index (E24) are found in Tables ( 3 and 4 ) and illustrated in Figs (4 and 5). These results show that all of the different dilution of SR 122 tested (1/1001/400) were able to emulsify crude oil- kerosene mixture and soybean oil but with different E24 values. Dilutions 1/100 and 1/150 were promising dilutions as they gave higher E24 values against crude oil-kerosene mixture $(72.1 \pm 1.0 \%$ and $77.4 \pm 0.9$ $\%$ respectively), and against soybean oil $(64.6 \pm 1.2 \%$ and 60.5 \pm 0.7 respectively). On the other hand dilution $1 / 200$ and $1 / 300$ gave E24 values of more than $66 \%$ against crude oil kerosene mixture and more than $57 \%$ against soybean, while dilution of $1 / 400$ was able to produce more than $50 \%$ E 24 value against both crude oil-kerosene mixture and soybean oil. From the above results dilution 1/150 was selected and tested against 9 different oil (Table 4, Fig 6). The results obtained show that the maximum E24 value was 100\% against crude oil followed by $77.4 \pm 0.9 \%$ (against crude oil-kerosene mixture) and 76.0 $\pm 1.0 \%$ against used motor oil. The least E24 was $15.0 \pm 0.5 \%$ against kerosene.

As for the E24 of SR 122 against vegetable oils (Table 4), the higher value was $60.5 \pm 0.7 \%$ against soybean oil, followed by $59.3 \pm 0.9 \%$ against olive oil and corn oil.

Willumsen and Kosaric (1997) and Lima et al (2011) proposed that an emulsification character is considered stable if its E24 corresponds to $50 \%$. Techaoei et al (2011) reported that one of the desirable characteristics of a biosurfactant is emulsification properties. Aniyanwu et al (2011) reported that the ability of a biosurfacant to emulsify hydrocarbon- water mixture has been demonstrated to enhance the biodegradation of the

\section{Volume 5 Issue 2, February 2016}




\section{International Journal of Science and Research (IJSR) \\ ISSN (Online): 2319-7064 \\ Index Copernicus Value (2013): 6.14 | Impact Factor (2014): 5.611}

hydrocarbons and is potentially useful in enhanced oil recovery. The ability of the biosurfactant to form stable emulsion with different hydrocarbons and vegetable oils gives to the biosurfactant many advantages in petroleum and pharmaceutical industries.

The application of biosurfactants in several fields of industries depends on their stability at wide range of temperatures, $\mathrm{pH}$ values and salinity (Khopade et al, 2012).

Results of thermostability of SR 122 showed that this product was able to maintain its surface activity (as measured by the ODA method) unaffected in a wide range of temperature even after heating at the autoclave temperature of $121^{\circ} \mathrm{c}$ for 20 minutes. This character gives this new bioproduct SR 122 a potential use in food, cosmetics and pharmaceutical industries, where heating to achieve sterility is required (Abouseoud et al, 2008). The thermostability characteristic also increases the potential application of the new bioproduct SR 122 in a broader perspective including at conditions where high temperature prevail as in biological enhanced oil recover (Khopade et al, 2012).

Results of the stability of SR 122 at different $\mathrm{pH}$ values show variation of its surface activity with the variation of $\mathrm{pH}$ values (2-11) as indicated by the variation of ODA values (Table 5). At $\mathrm{pH} 8$, the product showed its optimum surface activity $\left(142.0 \pm 2.8 \mathrm{ODA} \mathrm{cm}^{2}\right)$. This was followed by $\mathrm{pH} 7\left(136.5 \pm 2.1 \mathrm{ODA} \mathrm{cm} \mathrm{cm}^{2}\right)$ and $\mathrm{pH} 9$ $\left(124.0 \pm 5.1 \mathrm{ODA} \mathrm{cm}^{2}\right)$. These result show that the highest surface activity was achieved at slightly alkaline $\mathrm{pH}$ as well as the neutral $\mathrm{pH}$ values, although at the alkaline $\mathrm{pH}$ 9 high ODA value of $124.0 \pm 5.7 \mathrm{~cm}^{2}$ was recorded. The results also show that SR122 was able to retain $96.2 \pm$ $1.6 \%$ and $87.3 \pm 4.0 \%$ of its activity at $\mathrm{pH} 7$ and $\mathrm{pH} 9$ respectively ( this is relative to the optimum $\mathrm{pH} 8$ ). At the acidic $\mathrm{pH}$ values (2-5), it retained $53.5 \pm 0.6 \%$ to $64.8 \pm$ $2.0 \%$ of its activity, while at the higher $\mathrm{pH}$ values 10 and 11 it retained $79.6 \pm 3.0$ and $22.8 \pm 1.6 \%$ respectively.

As for the stability of this new SR 122 in the presence of different of $\mathrm{NaCl}(0-25 \%)$, the results (Table 6) show that the surface activity of this product (as tested by the ODA method) differ according to the differences in $\mathrm{NaCl}$ concentrations. It retained $99.1 \pm 2.2 \%-84.9 \pm 1.4 \%$ of its activities at $2-10 \% \mathrm{NaCl}$. At $15 \%$ and $20 \% \mathrm{NaCl}$ concentrations, it retained $74.1 \pm 1.8 \%$ and $72.8 \pm 0.0 \%$ respectively of its activity ( this is relative to $0.0 \% \mathrm{NaCl}$ ). These results confirm the stability of SR122 at wide range of $\mathrm{NaCl}$ concentrations $(2-20 \% \mathrm{w} / \mathrm{w})$. On the other hand it was able to retain $57.1 \pm 2.1 \%$ of its activity in presence of $25 \% \mathrm{NaCl}(\mathrm{w} / \mathrm{v})$.

Oil reservoirs are one of the harsh environments, where temperature can range from 20 to $90^{\circ} \mathrm{c}$, normal salinity to hyper saline and wide range of $\mathrm{pH}$ values (Al-Bahry et al, 2012). The new product SR122 meets those condition as it showed surface activity and stability over wide range of environmental factor. Accordingly, it represents a promising candidate for enhanced oil recovery and for using at commercial scale.
In the present work the potential characterics of the new bioproduct SR 122 can be summarized in the following points.

- Has high emulsification activity as indicated by the higher E24 values against petroleum oil; petroleum oil- kerosene mixture and used motor oil (100\%, 77.4\% and 76.0 respectively). At the same time it has promising E24 values against vegetable oils $(54.5 \%-60.5 \%)$.

- Has the ability to reduce the surface tension to $29.0 \mathrm{mN} / \mathrm{m}$ at a dilution of $1 / 100$.

- Highly reduces the interfacial tension between oil and water and between oil and solid surface as indicated from the higher ODA values and the results of the 12 wells porcelain plate method.

- It showed surface activity at wide range of temperature (0$\left.121^{\circ} \mathrm{c}\right), \mathrm{pH}$ values (2-11) and $\mathrm{NaCl}$ concentrations $(2 \%$ $25 \% \mathrm{w} / \mathrm{v})$.

- Non-toxic and cost-effective because it is of plant origin.

- It can be considered as an alternative to both microbial biosurfactants and the chemically synthesized surfactants.

All of the above characters give this new product (SR122) the potential uses in petroleum, pharmaceutical, cosmetics and food industries. It may be useful for cleaning oil- storage tanks, recovery of oil from oily sludge, washing oilcontaminated soils, enhanced oil recovery from reservoirs and enhancement of bioremediation processes.

In the present work the efficiency of SR 122 for cleaning oilcontaminated vessels was examined in the laboratory. The result show that after $2-3 \mathrm{~min}$ of the addition of $1 / 100$ and 1/150 dilutions of SR 122 solution, most of the oil was removed from the bottom and the wall of the tubes and floated over the SR 122 solution as a distinct phase (Fig 7, b-c). On the other hand large amount of oil was also recovered $10 \mathrm{~min}$ after the addition of 1/200 dilution of SR 122 solution (Fig 7, d), while very small amount of the oil was removed after 20 min of the addition of the diluted solution 1/300 (Fig. 7, e). When water was used as control, no covery of oil was observed even after $30 \mathrm{~min}$ (Fig 7, a).

On a large laboratory scale, SR122 (dil. 1/100) was applied for cleaning a microcosm representing an oil storage tank $(50 \times 30$ $x 30 \mathrm{~cm}$ ). Crude oil was stored in this tank for a period of more than 24 month, then the tank was emptied leaving the oily sludge covering the bottom (Fig. 8, a). 3 liters of the biosurfactant was introduced into the tank. (Fig. 8, b) which was left on a shaker operated at $120 \mathrm{rpm}$ for $96 \mathrm{~h}$ at room temperature. The results were observed and could be summarized in the following points:

- During 5-60 min of the addition of SR 122 solution, the oily material was gradually recovered and floated on the top of the liquid phase (Fig 8a-8d).

- At the end of $96 \mathrm{~h} /=$ more than $95 \%$ oil was recovered. The recovered oil floated as distinct phase covering nearly all the surface of SR 122 solution, leaving the bottom of the tank nearly clean.

- When about $3 \mathrm{~L}$ of water was added to the content of the tank, mixed and transferred to a new clean tank, the recovered oil was evenly spreaded over the aqueous phase. From this result it is of interest to observe a modification and reduction in the viscosity of the recovered oil. This may facilitate the pumping of this oil. 


\section{International Journal of Science and Research (IJSR) \\ ISSN (Online): 2319-7064 \\ Index Copernicus Value (2013): 6.14 | Impact Factor (2014): 5.611}

- At this point, the volume of the recovered oil could be measured and the cost of the operation can be estimated (this will be carried out further in a separate work).

The above results clearly show that the new product SR122 represents a good candidate for cleaning and recovery of oil from oil-contaminated vessels, oil-storage tanks, tank cars, oil tanks, pipelines and other containers used to transport or store crude oil. Such a clean process represents economically non-hazardous and cost-effective strategy as compared to other cleaning methods.

In the present work, when SR 122 was used for the cleaning process, the oil was mobilized without forming a suspension, this is through replacement technique, in which the oil was released from the system due to reduction in the interfacial tension, and then the oil was floated and remaind a distinct phase. Oil will undergo displacement if the interfacial tesnsion between oil solid is highly reduced to overcome the capillary force (Urum, 2004).

\section{Acknowledgements}

Table 2 : ODA values and/or diameter clear zone $(\mathrm{m} \mathrm{m})$ of some biosurfactant as recorded by different authors

\begin{tabular}{|c|c|c|}
\hline Microorganisms & ODA $\mathrm{Cm}^{2}$ & References \\
\hline Bacillus subtilis SH20 & $63.6 \pm 3.4$ & \multirow{3}{*}{ Diab and Eldin (2013) } \\
\hline Bacillus subtilis $\mathrm{SH} 20$ & $50.2 \pm 2.1$ & \\
\hline Pseudomonas aeruginosa $\mathrm{SH} 29$ & $63.0 \pm 2.8$ & \\
\hline $\begin{array}{l}\text { Pseudomonas aeruginosa } \\
\text { Bacillus subtilis }\end{array}$ & $\begin{array}{c}0.95(11 \mathrm{~mm}) \\
0.40(7 \mathrm{~mm})\end{array}$ & Chioma et al (2013) \\
\hline $\begin{array}{l}\text { Pseudomonas aeruginosa UKMP14T } \\
\text { Rhodococcus sp. }\end{array}$ & $\begin{array}{l}0.6(9 \mathrm{~mm}) \\
0.6(9 \mathrm{~mm})\end{array}$ & Hamza et al (2013) \\
\hline Pseudomonas oeruginosa L1 & $7.1(30 \mathrm{~mm})$ & \multirow{5}{*}{ Tambekar and Gadakh (2013) } \\
\hline P.aeruginosa $\mathrm{PVG} 1$ & $9.6(35 \mathrm{~mm})$ & \\
\hline P.aeruginosa PVG1 & $23.1(55 \mathrm{~mm})$ & \\
\hline P.aeruginosa $\mathrm{G} 2$ & $63.3(90 \mathrm{~mm})$ & \\
\hline Stenotrophomonas mulliphila & $12.52(40 \mathrm{~mm})$ & \\
\hline Acinetobacter sp MW1 & 2.45 & \multirow{6}{*}{ Dhail et al (2012) } \\
\hline 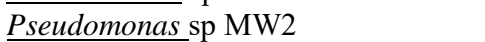 & 3.14 & \\
\hline Pseudomonas sp JN 2 & 2.55 & \\
\hline Bacillus sp JN1 & 2.55 & \\
\hline Glucobacter sp MS3 & 2.30 & \\
\hline Arthrobacter sp M51 & 2.22 & \\
\hline Bacillus subtilis N/o & $28.2(60 \mathrm{~mm}$ & El-Sersey (2012) \\
\hline Pseudomonas aeruginosa Y5 & $23.74(55 \mathrm{~mm})$ & \multirow{2}{*}{ Zhang et al (2012) } \\
\hline Pseudomonas aeruginosa $\mathrm{Y} 17$ & $26.40(58 \mathrm{~mm})$ & \\
\hline$\frac{\text { Pseudomonas }}{\text { SCMU106 }} \underline{\text { aeruginosa }}$ & $\begin{array}{c}143.2 \text { with }\left(\mathrm{NH}_{4}\right)_{2} \mathrm{H}_{2} \mathrm{PO}_{4} \\
110.6 \text { with } \mathrm{NH}_{4} \mathrm{H}_{2} \mathrm{PO}_{4} \\
11.17 \text { with } \mathrm{Na} \mathrm{No}_{3} \\
10.83 \text { with }\left(\mathrm{NH}_{4}\right)_{2} \mathrm{SO}_{4} \\
9.8 \text { with } \mathrm{NH}_{4} \mathrm{No}_{3}\end{array}$ & Techaoei et al (2011) \\
\hline $\begin{array}{l}\text { Bacillus sp } \mathrm{B} 2 \\
\text { Bacillus sp } 0517\end{array}$ & $\begin{array}{l}6.15(28 \mathrm{~mm}) \\
7.1(30 \mathrm{~mm})\end{array}$ & Violate et al (2011) \\
\hline $\begin{array}{l}\text { Bacillus subtilis } \mathrm{BS} 3 \\
\text { Pseudomonas aeruginosa } \mathrm{P} 3\end{array}$ & $\begin{array}{l}3.14(20 \mathrm{~mm}) \\
3.8(22 \mathrm{~mm})\end{array}$ & Priya and Usharani (2009) \\
\hline Picia anomals & 69.43 & Thaniyavarn et al (2008) \\
\hline Myroides sp SMI & 3.14 & \multirow{8}{*}{ Maneerat and phetrong (2007) } \\
\hline Vibrio paraheamolyticus SM2 & 1.13 & \\
\hline Bacillus subtilis SM3 & 2.55 & \\
\hline Micrococus luteurs SM4 & 1.13 & \\
\hline Acinetobacker antiratus SM 6 & 2.55 & \\
\hline$\overline{\text { Vibrio parcheamolyticus SM7 }}$ & 1.13 & \\
\hline Bacillus pumiless SM8 & 2.55 & \\
\hline Unidentified SP SM 5 & 2.01 & \\
\hline
\end{tabular}




\section{International Journal of Science and Research (IJSR) \\ ISSN (Online): 2319-7064}

Index Copernicus Value (2013): 6.14 | Impact Factor (2014): 5.611

Table 3: Emulsification index (E 24) of the different dilutions/ concentrations of SR 122 using crude oilkerosene mixture and soybean oil

\begin{tabular}{|c|c|c|c|}
\hline \multirow{2}{*}{$\begin{array}{c}\text { Dilution } \\
\text { (w/v) }\end{array}$} & \multirow{2}{*}{ Conc. g/l } & \multicolumn{2}{|c|}{ E24 (\%) } \\
\cline { 3 - 4 } & & Crude oil + kerosene & Soybean oil \\
\hline $1 / 100$ & 10 & $72.1 \pm 1.0$ & $64.6 \pm 1.2$ \\
\hline $1 / 150$ & 7 & $77.4 \pm 0.9$ & $60.5 \pm 0.7$ \\
\hline $1 / 200$ & 5 & $67.5 \pm 1.1$ & $57.8 \pm 0.3$ \\
\hline $1 / 300$ & 3.3 & $66.9 \pm 0.3$ & $57.2 \pm 0.6$ \\
\hline $1 / 400$ & 2.5 & $51.0 \pm 1.4$ & $56.5 \pm 1.4$ \\
\hline
\end{tabular}

Table 4: Emulsification index (E24) of the biosurfactant SR122 against different oils when 1/150 dilution was usd. $\mathrm{n}=2, \pm:$ standard directions

\begin{tabular}{|l|c|}
\hline \multicolumn{1}{|c|}{ Oils } & $E 24(\%)$ \\
\hline Crude oil (CO) & $100+0.0$ \\
Crude oil Kerosene (COK) & $77.4 \pm 0.9$ \\
Kerosene (K) & $15.0 \pm 0.5$ \\
Used motor oil (UO) & $76.0 \pm 1.0$ \\
Paraffin oil (P) & $57.7 \pm 1.2$ \\
\hline Soybean Oil (SO) & $60.5+0.7$ \\
Olive oil (Ol.O) & $59.3 \pm 0.9$ \\
Sunflower oil (SnO) & $54.5 \pm 0.4$ \\
Corn Oil (Cn O) & $59.3 \pm 1.1$ \\
\hline
\end{tabular}

Table 5: Stability of SR 122 at different $\mathrm{pH}$ values.

Retained activity (\%) is given relative to the activity at $\mathrm{pH}$ 8 (the optimum value) $n=2, \pm=$ standard deviation

\begin{tabular}{|c|c|c|}
\hline $\mathrm{pH}$ values & Activity $\left.(\mathrm{ODA} \mathrm{cm})^{2}\right)$ & Retained activity $(\%)$ \\
\hline 2 & $76.0 \pm 2.8$ & $53.5 \pm 0.6$ \\
3 & $81.0 \pm 1.4$ & $57.0 \pm 1.0$ \\
5 & $92.0 \pm 2.8$ & $64.8 \pm 2.0$ \\
7 & $136.5 \pm 2.1$ & $96.2 \pm 1.6$ \\
8 & $142.0 \pm 0.0$ & $100.0 \pm 0.0$ \\
9 & $124.0 \pm 5.1$ & $87.3 \pm 4.0$ \\
10 & $113.0 \pm 4.2$ & $79.6 \pm 3.0$ \\
11 & $32.5 \pm 2.1$ & $22.2 \pm 1.6$ \\
\hline
\end{tabular}

Table 6: Slability of SR122 at different $\mathrm{NaCl}$ concentrations Retained activity (\%) is given relative to the activity at $0 \% \mathrm{NaCl}$ $\mathrm{n}=2, \pm:$ standard deviation

\begin{tabular}{|c|c|c|}
\hline $\begin{array}{c}\text { NacL concentrations } \\
(\% \mathrm{w} / \mathrm{v})\end{array}$ & $\begin{array}{c}\text { Activity } \\
\left(\mathrm{ODA} \mathrm{cm}^{2}\right)\end{array}$ & $\begin{array}{c}\text { Retained } \\
\text { activity }(\%)\end{array}$ \\
\hline 0 & $162.0 \pm 0.0$ & $100.0 \pm 0.0$ \\
2 & $1605 \pm 3.5$ & $99.1 \pm 2.2$ \\
3 & $156.5 \pm 2.1$ & $96.6 \pm 1.2$ \\
5 & $147.0 \pm 2.8$ & $90.7 \pm 1.2$ \\
10 & $137.5 \pm 2.1$ & $84.9 \pm 1.4$ \\
15 & $120.0 \pm 2.8$ & $74.1 \pm 1.8$ \\
20 & $118.0 \pm 0.0$ & $77.8 \pm 0.0$ \\
25 & $92.5 \pm 3.5$ & $57.1 \pm 2.1$ \\
\hline
\end{tabular}

\section{References}

[1] Abouseoud, M., Maachi, R., Amrane, A., Boudergua, S., Nabi, A. 2008 Evaluation of different carbon and nitrogen sources in production of biosurfactant by Pseudomonas_flourescens. Desalination, 223: 143151.

[2] Al-Bahry, S.N., Al-wahaibi, Y.M., Elshafie, A.E., AlBemani, A.S., Joshi, S.S., Al-Makhamri, H.S., AlSulaimani, H.S. 2012. Biosurfactant production by Bacillus subtilis_B20 using date molasses and its possible application in enhanced oil recovery. Int Biodeter. Biodegrad. XXX: 1-6.

[3] Anyanwu, C.U., Obi, S.K.C., Okolo, B.M. 2011. Lipopeptide biosurfactant produced by Serratia merscens NSK-1 strain isolated from petroleum contaminated soil. J. Appl. Sci. Res. 7(1): 79-87.

[4] Banat, I.M., Makkar, R.S., Comeotra, S.S. 2000 Potential commercial applications of microbial surfactants. Appl. Microbial. Biotechnol. 53:495-508.

[5] Chioma, O., Ogechukwu, M., Bright, O. Simon, O. Chinyere, A. 2013. Isolation and characterization of biosurfactant- producing bacteria from oil-polluted soil. J.Natural Sci. Res. 3 (5): 119-122.

[6] Diab, A., and El Din, S.G. 2013 (a). Production and characterization of biosurfactants produced by Bacillus spp and Pseudomonas spp isolated from the rhizosphere soil of an Egyptian salt marsh plant. Nature and Science, 11(5): 103-112.

[7] Diab, A. and El Din. S.G. 2013 (b). Application of the biosurfactants produced by Bacillus spp ( $\mathrm{SH} 20$ and $\mathrm{SH}$ 26) and Pseudomonas aeruginosa SH 29 isolated from the rhizosphere of an Egyptian salt march plant for the cleaning of oil- contaminated vessels and enhancing the biodegradation of oily sludge. Afr. J. Environ. Sci. Technol. 7 (7) : 671-679.

[8] Dhail, S. and Jasuja, N.D. 2012. Isolation of biosurfactantproducing marine bacterial. Afr. J. Environ. Sci. Technol. $6(6): 263-266$.

[9] El-Sersey, N.A. 2012. Plackett-Burman Design to optimize biosurfactant production by marine Bacillus $\underline{\text { sublitis }} \mathrm{N}$ 10. Romainan Botechnology letters 17(2): 7049-7064.

[10] Gnanamani, A., Kavitha, V., Radhakrishnan, N., Mandal, A.B. 2010. Bioremdiation of crude oil contamination using microbial surface-active agents isolation production and characterization. J. Bioremed. Biodegrade. 1: 107. Dio: 10.4172/2155-6199.1000107.

[11] Haddad, N.I.A., Wang, Ji, Bazhong, Mu. 2009. Identification of a biosurfactant producing strain: Bacillus subtilis HOB2. Protein and Peptide letters, 16: 7-13.

[12] Hamzah, A., Sabturani, N., Radiman, S. 2013. Screening and optimization of biosurfactant production by the hydrocarbon-degrading bacterial. strains Malaysiana, 42(5):615-623.

[13] Khopade, A., Biao, R., Liu, X., Mahadik, K., Zhang, L, Kakare, C. 2012. Production and stability studies of biosurfacant isolated from marine Nocardiopsis sp. B4. Desalination, 285: 198-204.

[14] Li, R. 2006, Soy product off-flavor generating masking and flavor creating. In : Soy applications in food; Raiz, M.N. Ed; Taylor and Fancis; Boca Rakon, FL, USA, pp: 227-248.

[15] Lima, T.M.S., Fonseco, A. F., Leao, B.A., Houndeer, A.H. Totala, M.R., Borges, A.C. 2011. Oil recovery from oil fuel oil storage tank sludges using biosurfactants. J. Bioremed. Biodegrat. 2: 125-137.

[16] Maneerat, S. and Phetrong, K. 2007. Isolation of biosurfactant- producing marine bacteria and characteristics of selected biosufrfactant. Songklamakarin J. Sci. Technol. 29 (3): 781-791

[17] Mukherjee, S., Das, P., Sen, R. 2006. Twards commercial production of microbial surfactants. Trends Biotechnol 24: 509-515. 


\section{International Journal of Science and Research (IJSR) \\ ISSN (Online): 2319-7064}

Index Copernicus Value (2013): 6.14 | Impact Factor (2014): 5.611

[18] Oakenfull, D. 1981. Saponins in food- A review: food chem.. 6: 19-40.

[19] Pereira, J.F.B., Guddina, E.J., Costa, R., Vitorino, R. Teixeira, J.A., Coutinho, J.A.P., Rodrigues, L. R. 2013. Optimization and characterization of biosurfactant production by Bacillus subtilis isolates towards microbial enhanced oil recovery applications. Fuel, 111:259-268.

[20] Priya, T. and Usharani, G. 2009. Comparative study for biosurfactant production by using Bacillus subtilis and Pseudomonas aeruginos. Botany Research International 2 (4): 284-287.

[21] Tabatabaee, A. Assadi, M.M., Noohi, A.A., Sajadien, V.A. 2005. Isolation of biosurfactant-producing bacteria from oil reservoirs. Iran. J. Environ. Health. Sci. Eng. 2 (1): 6-12.

[22] Techaoei, S., Lumyon, S., Parthumpai, W., Santiarwarn, D. Leelapornpisid, P. 2011. Screening characterization and stability of biosurfactant produced by Pseudomonas aeruginosa SCMU106 isolated from soil in Northern Thailand. Asian J. Biol, Sci 1-12. D01:10.3923/ajbs.

[23] Tabatabaee, A. Assadi, M.M., Noohi, A.A., Sajadien, V.A. 2005. Isolation of biosurfactant-producing bacteria from oil reservoirs. Iran. J. Environ. Health. Sci. Eng. 2 (1): 6-12.

[24] Tamberkar, D.H. and Gadakh, P.V. 2013. Bochemical and molecular detection of biosurfactant producing bacteria from soil. Int. J. Life Sci. Bt and Farm Res. 2 (1): 204-211.

[25] Thaniyavarn, J., Chainsuthai, T., Sangvanich, P., Roongsawing, N., Washio, K., Morikawa, M., Thaniyavarn, S., 2008. Production of sophorolipid biosurfactant by Pichia anomala. Biosci. Biotechnol. Biochem. 72: 2061-2068.

[26] Urum, K., 2004. Biosurfactant enhanced treatment of petroleum oil contaminated soile. Ph.D. Thesis. Chemical Engneering School of Engineering and Physical Sciences, Heriot-Watt University.

[27] Vencken, J. P., Heng, L., Groot, A., Gruppen, H. 2007. Saponins, classification and occurrence in the plant kingdom. Phytochemistry, 68: 275-297.

[28] Violeta, O., Oana, S., Matilda, C., Maria, C.D., Catalina, V., Gheorghe, C., Petruda, C.C. 2011. Production of biosurfactant and antifungal compounds by new strains of Bacillus spp isolated from different sources. Romanian Biotechnol letters, 16 (1): 84-91.

[29] Willumsen, P.A. and Karlson, U. 1997. Secreening of bacteria isolated from PAH- contaminated soils, for production of biosurfactants and bioemmulsifiers. Biodgradation, 7: 415-423.

[30]Xu, Q, Nakajima, M., Liu, Z., Shiina, T. 20011. Biosurfactant for microbubble preparation and applications. Int. J. Mol. Sci. 12: 462-475.

[31]Zheng, C., Wang, M., Wang, Y., Haung, Z. 2012 Optimization of biosurfactant mediated oil extraction from oil sludge. Bioresource Technology, 110:338-342.

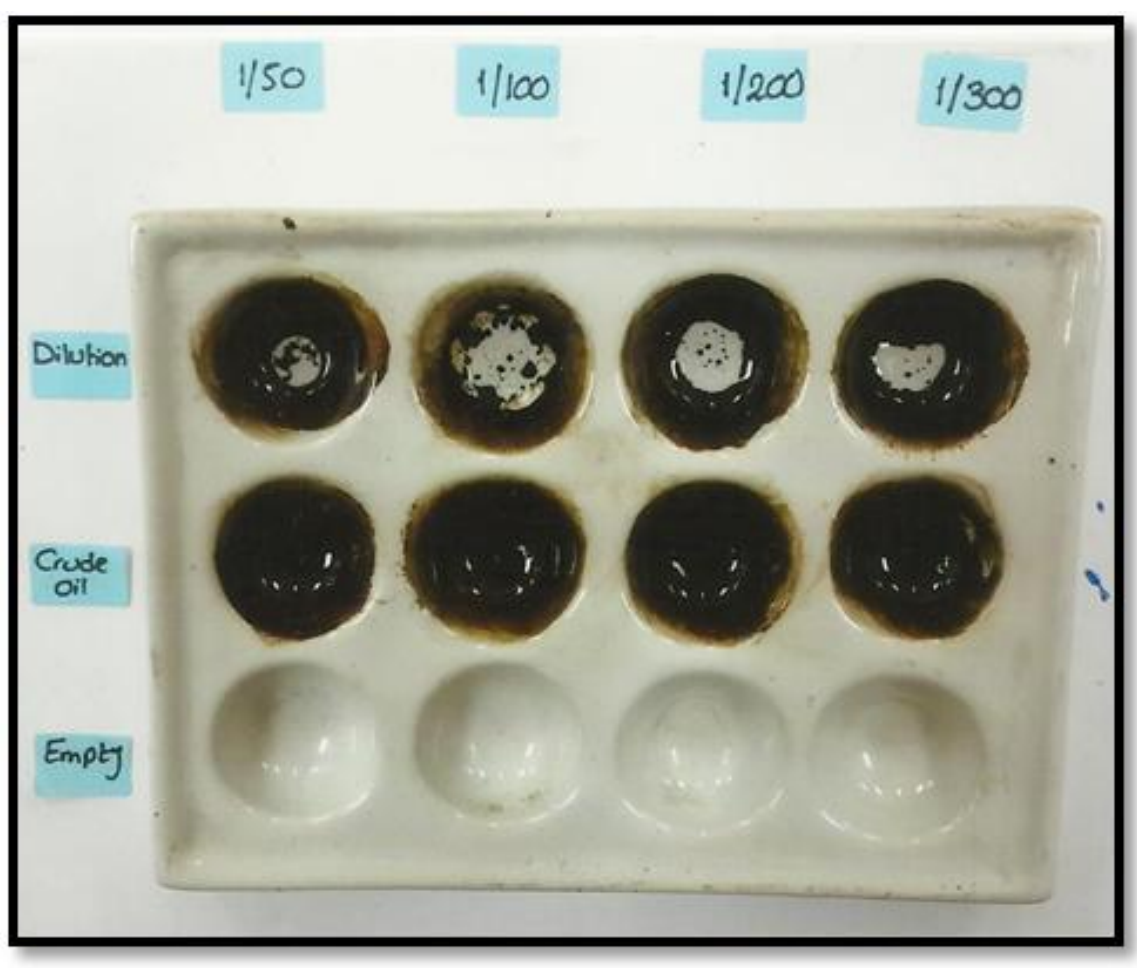

Figure 1: Screening the surface activity of the different concentrations of SR122 using the porcelain plate method. Visible clear zones indicate positive surface activity. 


\section{International Journal of Science and Research (IJSR) \\ ISSN (Online): 2319-7064}

Index Copernicus Value (2013): 6.14 | Impact Factor (2014): 5.611

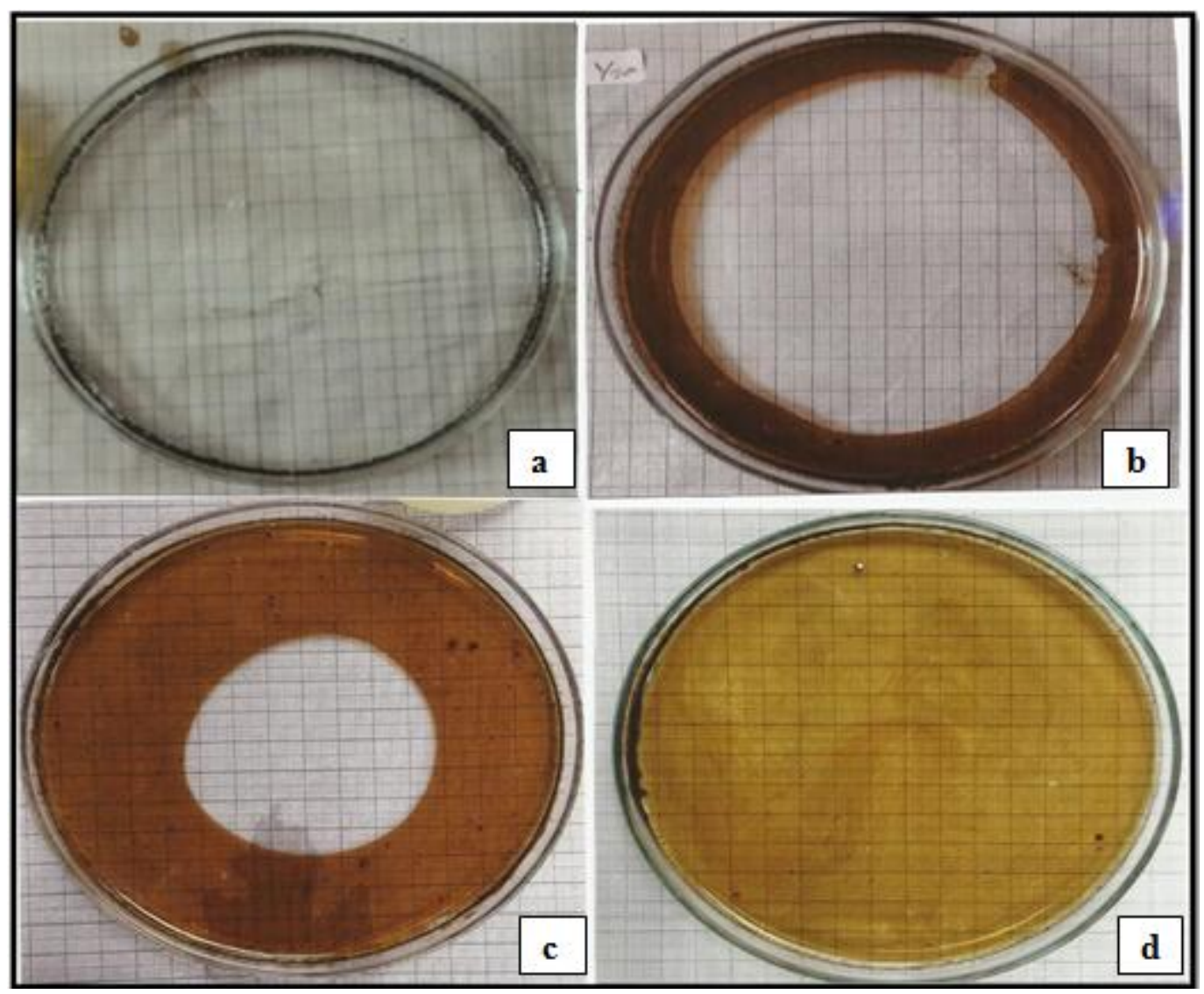

Figure 2:

Surface activity of the product SR122 at different concentrations using the ODA method:

a - Dilution 1/100 showing ODA of $171.0 \mathrm{~cm}^{2}$.

b - Dilution 1/200 showing ODA of $103 \mathrm{~cm}^{2}$.

c - Dilution of $1 / 300$ showing $44 \mathrm{~cm}^{2}$ ODA.

d - Oil spreader layer on the water surface prior the addition of SR122.

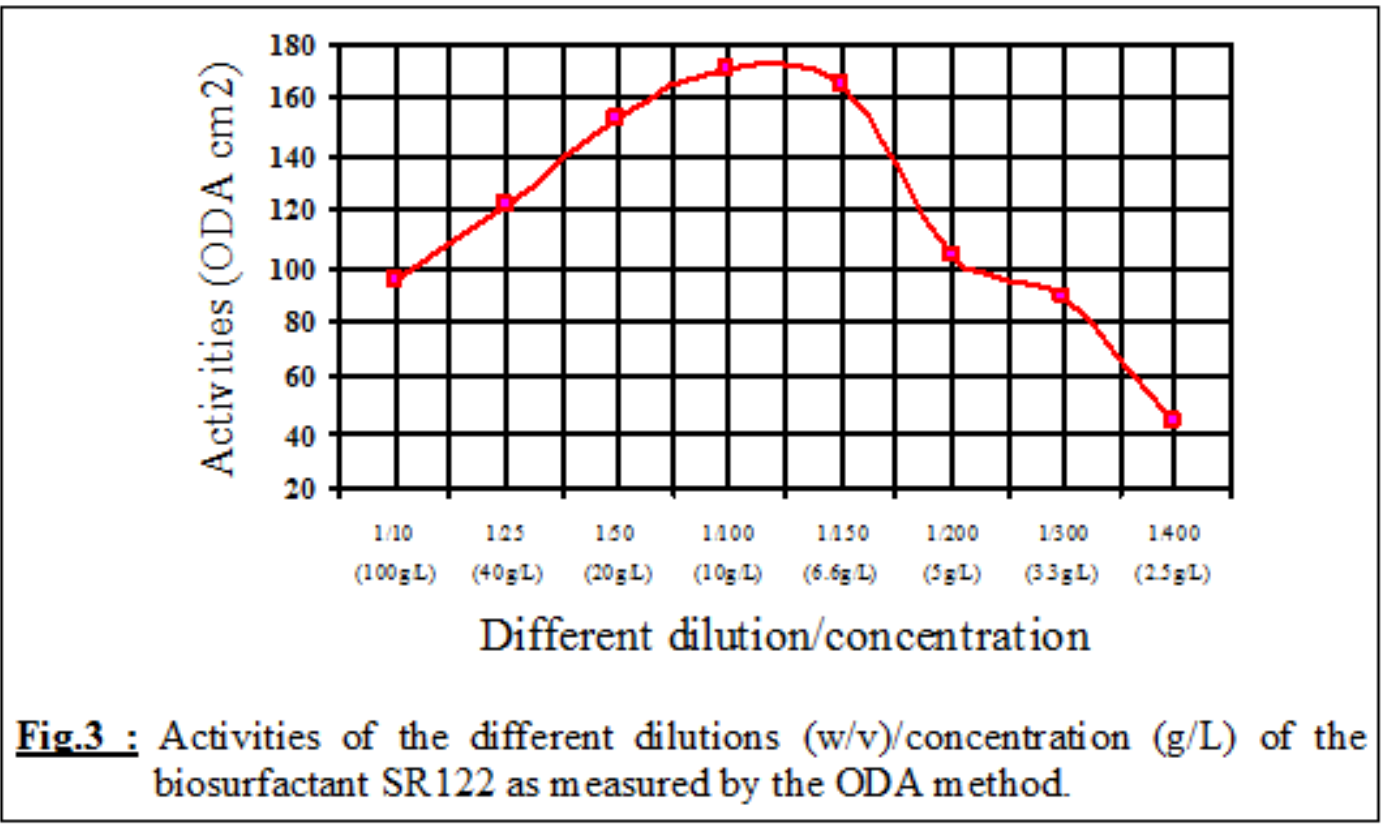

Volume 5 Issue 2, February 2016

www.ijsr.net 
International Journal of Science and Research (IJSR)

ISSN (Online): 2319-7064

Index Copernicus Value (2013): 6.14 | Impact Factor (2014): 5.611

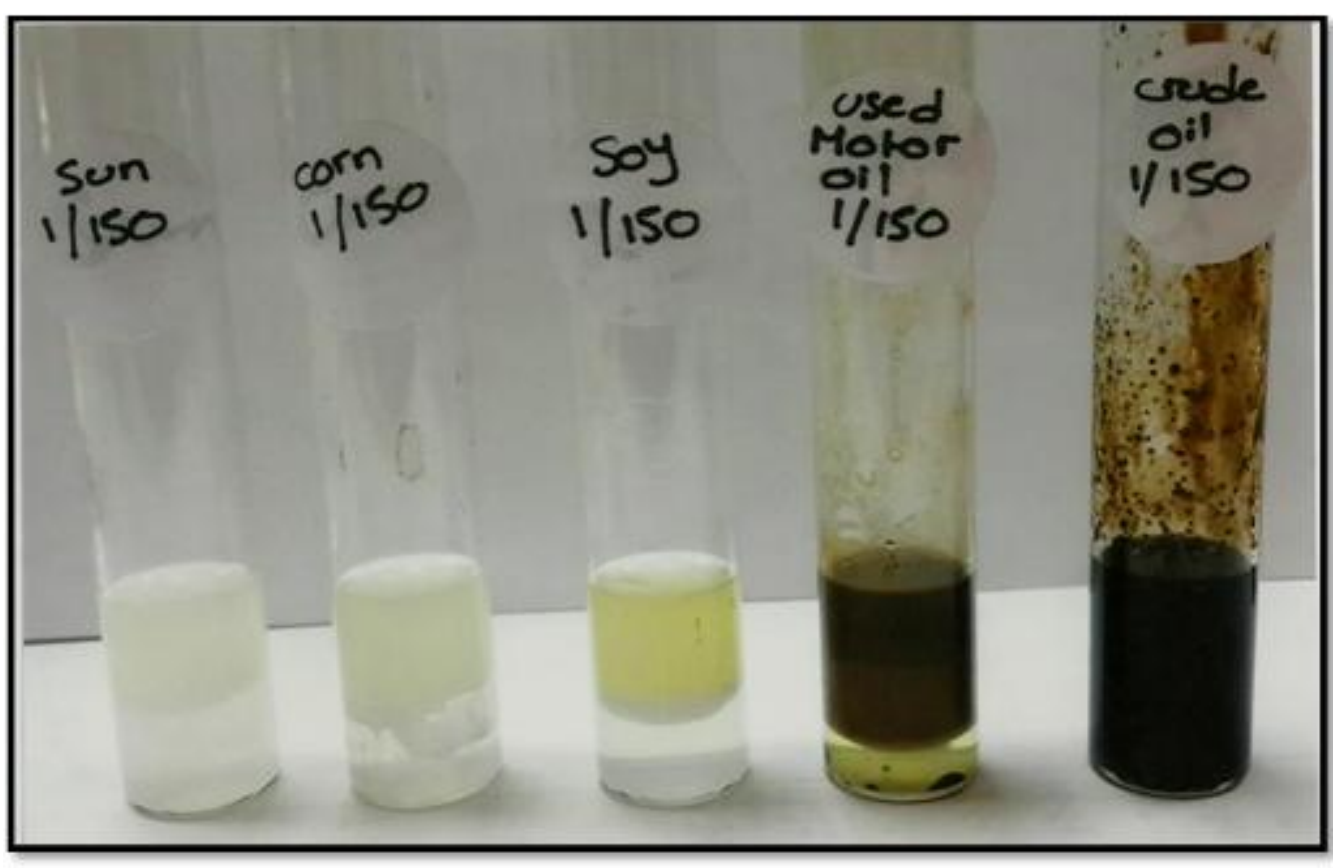

Figure 4:

Emulsification index (E24) of SR122 with different oils:

Sunflower oil, corn oil, soybean oil, used motor oil and crude petroleum oil.

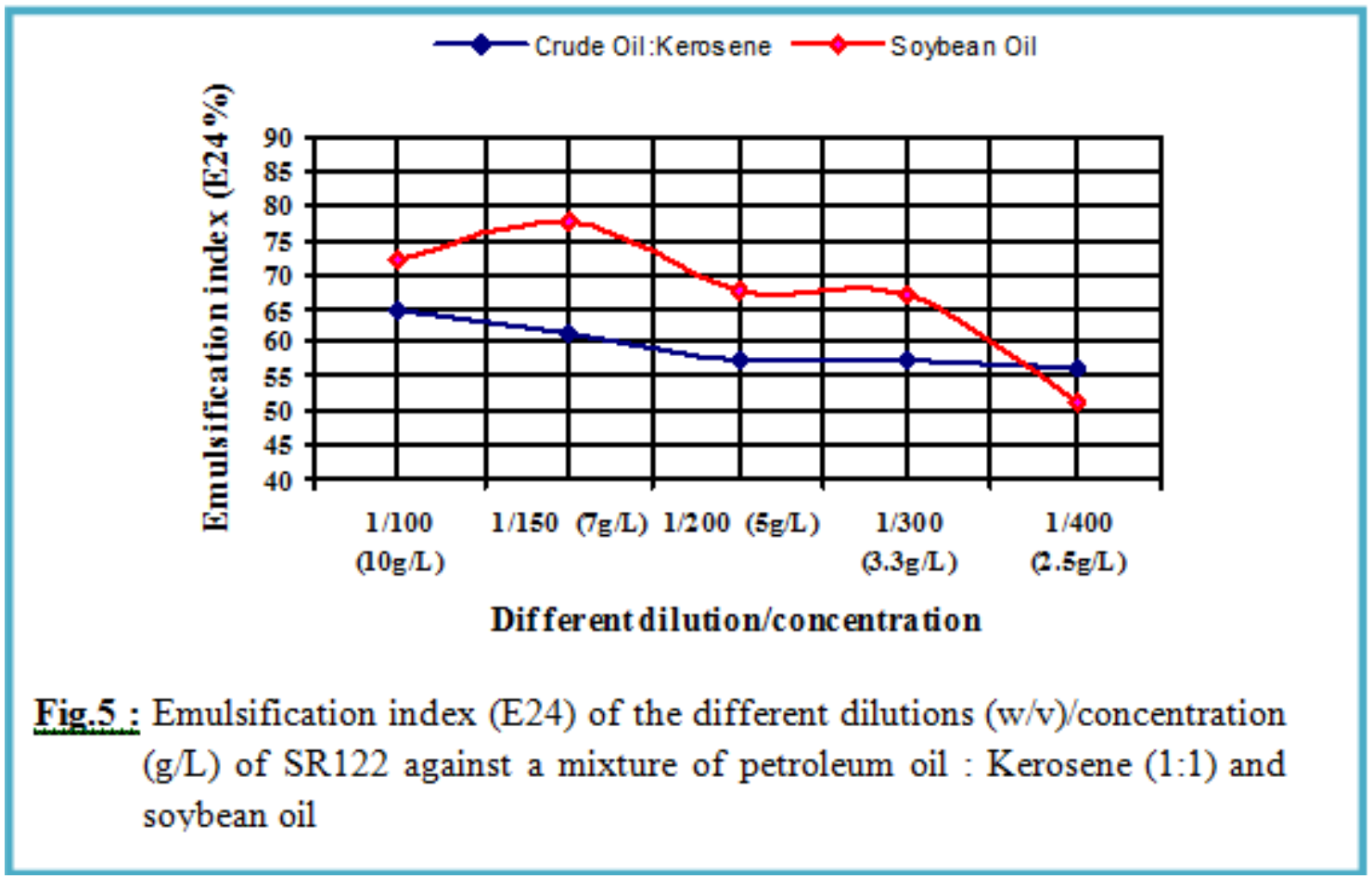

Volume 5 Issue 2, February 2016

www.ijsr.net 
International Journal of Science and Research (IJSR)

ISSN (Online): 2319-7064

Index Copernicus Value (2013): 6.14 | Impact Factor (2014): 5.611

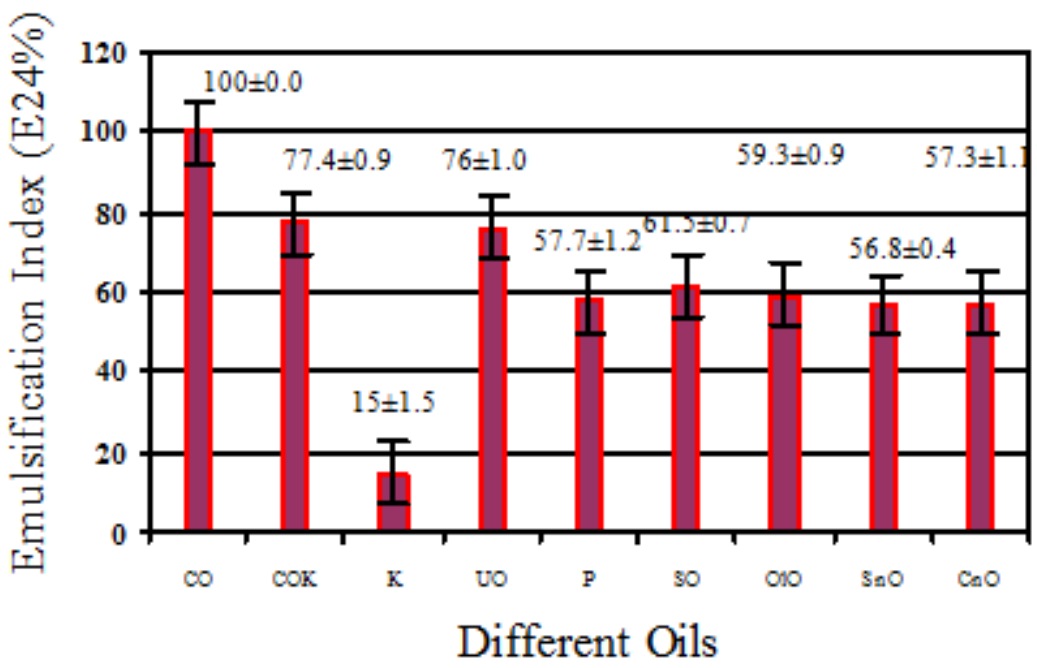

Fig.6. Emulsification index (E24\%) of the SR122 bioproduct against crude oil (CO), crude oil : kerosene (COK), kerosene (K), used motor oil (UO), paraffin oil $(\mathrm{P})$, soybean oil (SO), olive oil $(\mathrm{OlO})$, sunflower oil $(\mathrm{SnO})$, and com pị $(\mathrm{Cn}+\underline{0})$

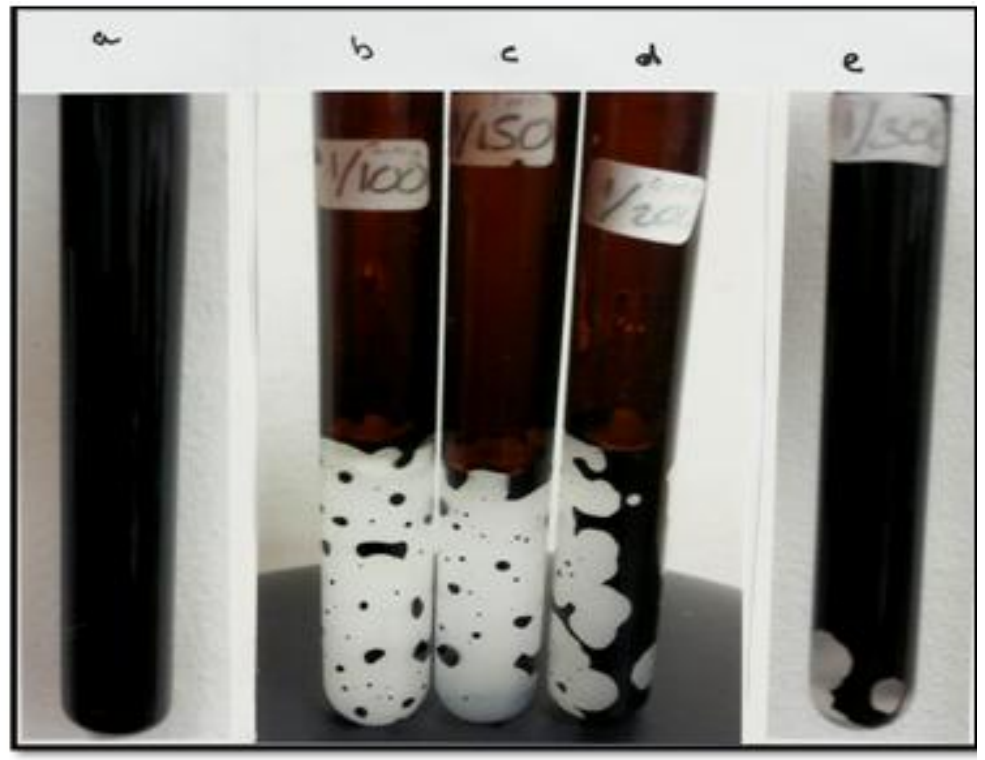

Figure 7: Application of SR122 for cleaning oil Contaminated tubes (pipes).

a- Control tube with water after 30 min of starting the experiment.

b-two minutes after the addition of 1/100 dilution of SR122.

c - Two minutes after the addition of $1 / 150$ dilution of SR122.

d - Ten minutes after the addition of $1 / 200$ dilution of SR122.

e - 20 minutes after the addition of $1 / 300$ of SR122. 


\section{International Journal of Science and Research (IJSR) \\ ISSN (Online): 2319-7064}

Index Copernicus Value (2013): 6.14 | Impact Factor (2014): 5.611
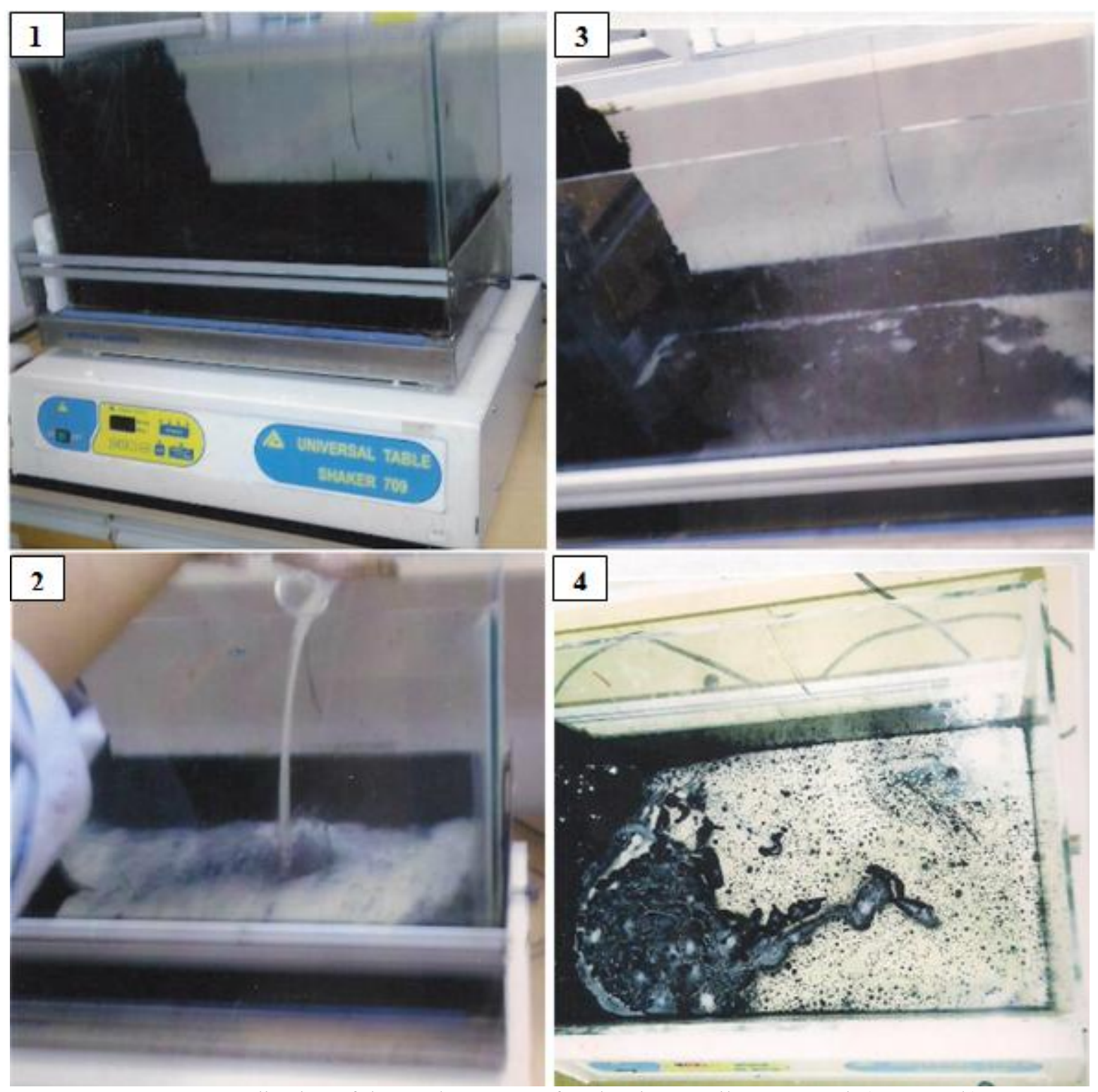

Figure 8: Application of the product SR122 for cleaning an oil storage tank (Open tank).

1. The tank after removing the 24 month storage oil and putting the tank on a shaker. Parts of the walls are covered with a layer of oil, and oily sludge was formed in the bottom of the tank.

2. Introducing the product SR122into the tank, and left on a shaker operated at $120 \mathrm{rpm}$.

3. After 20 minutes of the addition of SR122 (Top view).

4. After 60 minutes of the addition of SR122 (Side view). 